Gut, 1986, 27, 919-925

\title{
Latent pulmonary involvement in Crohn's disease: biological, functional, bronchoalveolar lavage and scintigraphic studies
}

\author{
P BONNIERE, B WALLAERT, A CORTOT, X MARCHANDISE, Y RIOU, \\ A B TONNEL, J F COLOMBEL, C VOISIN, AND J C PARIS \\ From the Clinique des maladies de l'appareil digestif, and Service associé de médecine nucléaire, Cité \\ Hospitalière, Lille; Département de pneumologie, and Service d'explorations fonctionnelles respiratoires, \\ Hôpital Calmette, Lillè, France
}

SUMMARY We have investigated the following pulmonary related parameters in 22 patients with Crohn's disease who were free of clinical pulmonary symptoms and had normal chest roentgenograms and in 25 controls: serum angiotensin converting enzyme, pulmonary function tests, bronchoalveolar lavage (lymphocyte count and subpopulations, macrophage viability and superoxide anion release by macrophages) and pulmonary scannings. Serum angiotensin converting enzyme was lower in Crohn's disease $(14 \cdot 1 \pm 5 \cdot 1)$ than in controls $(25 \cdot 2 \pm 4 \cdot 7)$ $(\mathrm{p}<0.001)$. Twelve of 22 Crohn's disease $(54 \%)$ had a bronchoalveolar lavage lymphocytosis ( $>18 \%$ alveolar lymphocytes). Bronchoalveolar lavage lymphocytes subpopulations were quite variable. Twelve of 17 Crohn's disease (71\%) had an increase spontaneous and/or stimulated superoxide anion production by alveolar macrophages. Six of 12 Crohn's disease $(50 \%)$ had an increase physiologic dead space in the upper part of their lung against one of 11 controls $(9 \%)$. These data suggest that most patients with Crohn's disease have a latent pulmonary involvement.

Systemic manifestations are frequent in inflammatory bowel disease, but classically the lung was regarded as rarely involved. ${ }^{12} \mathrm{~A}$ few recent reports, however, have described pulmonary manifestations occuring in patients with inflammatory bowel disease: bronchial suppuration, or bronchiectasis, ${ }^{3-5}$ granulomatous lung disease, ${ }^{6}$ diffuse or localised interstitial fibrosis ${ }^{7-12}$ and sulphasalazine pneumonitis. ${ }^{13-21}$

The rarity of pulmonary clinical manifestations contrasts with striking abnormalities of pulmonary function tests described in patients with inflammatory bowel disease: reduced lung transfer factor, increased residual volume, or decreased forced expiratory volume in one second. ${ }^{22-26}$

We have attempted to determine the actual frequency of pulmonary tests and bronchoalveolar abnormalities in patients with Crohn's disease and without clinical or radiological pulmonary abnormalities. ${ }^{2728}$ Furthermore, we tried to clarify

Address for correspondence: A Cortot, Clinique des maladies de l'appareil digestif, Cité Hospitalière, I,Place de Verdun 59037 Lille Cedex, France. Received for publication 29 November 1985. the pulmonary abnormalities mechanism by carrying out pulmonary scintigraphic studies in those patients.

\section{Methods}

PATIENTS

Twenty two patients with Crohn's disease were included in the study. There were 11 women and 11 men, 18-44 years old (mean age $28 \pm 7.8$ years). Eleven were cigarette smokers. None had a previous history of pulmonary disease or chest radiograph abnormalities. Physical examination and chest radiographs were normal in all patients at the time of the study. The length of Crohn's disease history at the onset of the study ranged from one month to 22 years (mean duration $41 \pm 57$ months). Small bowel alone was involved in one case, colon alone in nine cases, and the localisations were multiple in 12 patients (stomach, small bowel, colon, rectum, anus). Eight patients had active anal Crohn's disease and 10 systemic manifestations: arthralgia (five), ankylosing spondylitis (three), aphtous ulcers (two). Mean Crohn's Disease Activity Index (CDAI) ${ }^{29}$ was 
$207 \pm 86(50-383)$. Six patients had quiescent disease $(\mathrm{CDAI}<150)$ at the time of the study. Four patients had received sulphasalazine $(1.5 \mathrm{~g}-3 \mathrm{~g} / \mathrm{day}$ for the previous three months to three years), one prednisolone $(0.5 \mathrm{mg} / \mathrm{kg}$ body weight for the previous three weeks) and 10 metronidazole $(1 \mathrm{~g}-1 \cdot 5 \mathrm{~g} / \mathrm{day}$ for the previous three months).

\section{CONTROL SUBJECTS}

The control group included hospital staff and other healthy volunteers. There were 25 controls subjects for bronchoalveolar lavage (13 were cigarette smokers), nine women and 16 men, 24-46 years old (mean age $34 \pm 7$ years). Thirteen controls were tested for alveolar cell function studies (nine were cigarette smokers), five women and eight men, 22-46 years old (mean age 31 \pm 7 years). Eleven controls were tested for pulmonary scintigraphic studies (six were cigarette smokers), three women and eight men, 22-45 years old (mean age $29 \pm 6$ years).

\section{BRONCHOALVEOLAR LAVAGE}

Informed consent was obtained from all patients. Bronchoalveolar lavage was done using a technique which has been previously described. ${ }^{30}$ Total number and differential cell count were determined in lavage fluid. Cellular viability of alveolar macrophages was assessed by trypan blue exclusion. The state of activation of alveolar macrophages was evaluated with a lucigenin-dependent chemiluminescence method with or without phorbolmyristate-acetate and with or without superoxide dismutase in 17 Crohn's disease patients and 13 controls. ${ }^{31}$ Results are expressed as relative luminescent units per $0.5 \times 10^{6}$ viable macrophages.

The proportions of $T$ cells, helper cells and suppressor cells were determined in 10 cases using monoclonal antibodies respectively for $\mathrm{OKT}_{3}$, $\mathrm{OKT}_{4}$, and $\mathrm{OKT}_{8}$ that are specific for the lymphocyte subsets.

A second bronchoalveolar lavage was repeated in five patients with initially active Crohn's disease six months later their CDAI being $<150$.

\section{PULMONARY FUNCTION TESTS}

These were carried out at rest and included forced vital capacity (FVC) and forced expiratory volume in one second (FEV 1). Residual volume (RV) was quantified with the helium dilution method. Total lung capacity (TLC) was calculated from: TLC $=$ RV +FVC. Carbon monoxide diffusing capacity (DLCO) was studied using a steady state method. The predicted values for each subject based on sex, age, and height were obtained from standard tables. All data were expressed as percentage of the predicted values. Pulmonary function was regarded as abnormal when total lung capacity, forced vital capacity and/or forced expiratory volume in one second were less than $80 \%$ of predicted values and/or when carbon monoxide diffusing capacity was less than $75 \%$ of that predicted. ${ }^{32}$

\section{${ }^{67}$ GALLIUM $\left({ }^{67} \mathrm{Ga}\right)$ SCANNING}

Each patient received, 72 hours before scanning, $35 \mu \mathrm{Ci} / \mathrm{kg}$ of body weight ${ }^{67} \mathrm{Ga}$ citrate intravenously. Accumulation of ${ }^{67} \mathrm{Ga}$ in the lung and mediastinum was compared with ${ }^{67} \mathrm{Ga}$ uptake in the liver and in the shoulders soft tissue.

\section{PULMONARY SCANNING}

Pulmonary scanning included: (1) a ventilatory scanning obtained in a sitting position by respiration of gaseous Xenon $(1 \mathrm{mCi} / \mathrm{l})$ which provided a steady state ventilation picture, the total lung height and a recording of lung emptying at one minute. The pulmonary gas retention was estimated by the percentage of gas remaining in the lung at one minute. The distribution of gaseous Xenon was pictured so that a 'centre of gravity' or 'barycentre' of the lung ventilation could be determined. Radiation exposure was: $8.3 \mathrm{mRad}$ for lungs, $0.09 \mathrm{mRad}$ for whole body. (2) a perfusion scanning after slow intravenous infusion of Technetium albumin macroaggregates in a sitting position $(1 \mathrm{mCi})$. Abnormal distribution of lung perfusion was detected as well as the vertical perfusion gradient from the top to the lung basis. The distribution of macroaggregates was recorded so that a 'centre of gravity' of the lung perfusion could be determined. (3) the distance $\operatorname{delta}(\Delta)$ between the two 'centre of gravity' was determined and expressed as percentage of the total lung height.

\section{BLOOD TESTS}

Serum angiotensin-converting enzyme assay was carried out in all patients ${ }^{33}$ as well as beta-2microglobulin ${ }^{34}$ and circulating immune complexes by 121-I-Clq binding activity and by polyethylene glycol precipitation technique.

\section{STATISTICAL METHODS}

Results were expressed as mean value $(\mathrm{m}) \pm$ one standard deviation. The two-tailed $t$ test was used for comparison of data between patients and controls.

\section{Results}

All patients were free of clinical pulmonary symptoms and had normal chest radiograph findings. 


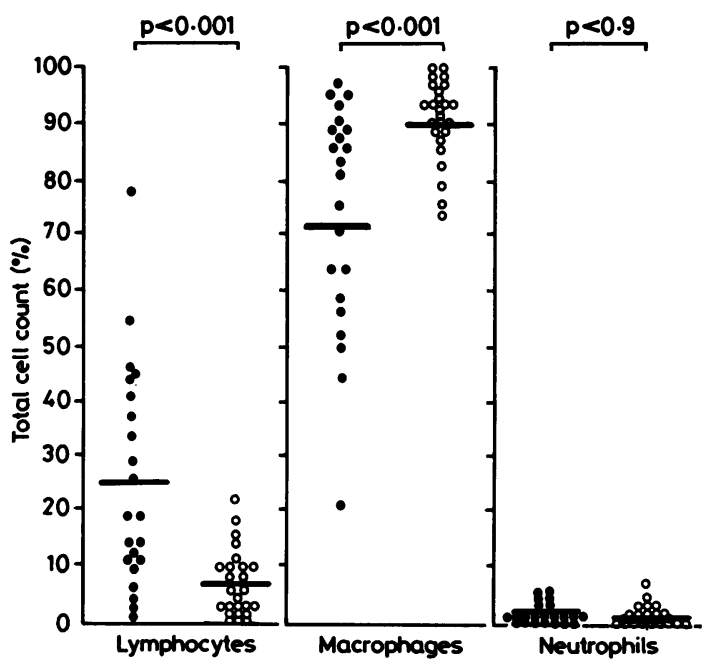

Fig. 1 Cell count (lymphocytes macrophages and neutrophils) in alveolar liquid after bronchoalveolar lavage $(B A L)$ in 25 normal volunteers $(O)$ and 22 Crohn's disease patients (O).

1a BAL DATA: LYMPHOCYTES

Total bronchoalveolar lavage recovery fluid $(109 \pm 86 \mathrm{ml})$, total number cells $\left(14 \cdot 1 \pm 5 \cdot 8 \times 10^{6}\right)$ were identical in patients and controls according to smoking habits. Alveolar lymphocytes percentages were higher in patients $(25 \cdot 1 \pm 19 \cdot 7 \%)$ than in controls $(7.2 \pm 8 \%)(\mathrm{p}<0.001)$ (Fig. 1).

Alveolar lymphocytes percentages were above $18 \%$ (controls mean $+2 \mathrm{SD}$ ) in 12 of 22 patients $(54 \%)$ who were defined as having an alveolar lymphocytosis. Percentages of T3 lymphocytes were the same in patients $(69 \cdot 7 \pm 8 \cdot 1 \%)$ and controls $(64 \pm 4 \cdot 5 \%)$. T4/T8 ratio were increased in three patients, normal in four and low in three (Table 1).

Five patients had a second bronchoalveolar lavage six months later showing a persistent alveolar lymphocytosis in four cases and a persistent normal bronchoalveolar lavage in one.

\section{1 b BAL DATA: MACROPHAGES}

Cellular viability of macrophages were identical in patients and controls: $83 \cdot 7 \pm 11 \cdot 1 \%$ and $84 \cdot 6 \pm 8 \cdot 9 \%$. Spontaneous chemiluminescence of bronchoalveolar lavage cells was higher in patients $(4567 \pm 4025)$ than in controls $(954 \pm 385$ relative luminescent units) $(p<0 \cdot 01)$. Similarly phorbolmyristate-acetate induced chemiluminescence was significantly increased in patients $(23824 \pm 11257$ relative luminescent units) as compared with controls (14392 \pm 6213 relative luminescent units) $(\mathrm{p}<0.025)$. Values vary widely but were higher than mean $+2 \mathrm{SD}$ in 12 of 17 patients with Crohn's disease $(70 \%)$ (Fig. 2). Superoxide dismutase reduced spontaneous and phorbolmyristate-acetate induced chemiluminescence of alveolar cells respectively by $70 \%$ and $91 \%$. The extent of chemiluminescence suppression by superoxide dismutase suggests that superoxide anion is involved in its production.

\section{PULMONARY FUNCTION TESTS}

All but one patient had normal carbonic acid gas and oxygen blood levels (pO2) at rest. Tests were abnormal in 15 of 21 patients. Total lung capacity, forced vital capacity and forced expiratory volume in one second were decreased in two cases associated with low diffusing capacity in one of the two.

Table 1 Alveolar lymphocytes subpopulations collected by bronchoalveolar lavage in five controls and 10 Crohn's disease patients. Alveolar lymphocytes are expressed as percentage of total alveolar cell count. Lymphocyte subpopulations are expressed as percentage of total number of alveolar lymphocytes.

\begin{tabular}{|c|c|c|c|c|c|}
\hline & $\begin{array}{l}\text { Alveolar } \\
\text { lymphocytes \% }\end{array}$ & $\begin{array}{l}\mathrm{OKT}_{3}^{+} \\
\%\end{array}$ & $\begin{array}{l}\mathrm{OKT}_{4}^{+} \\
\%\end{array}$ & $\underset{\%}{O K K T_{8}^{+}}$ & $O K T_{4}{ }^{+} / O K T_{8}{ }^{+}$ \\
\hline Controls $(n=5)$ & $11 \cdot 5 \pm 6^{*}$ & $64 \pm 4 \cdot 5$ & $44 \pm 2 \cdot 7$ & $30 \pm 1 \cdot 3$ & $1 \cdot 5 \pm 0 \cdot 15$ \\
\hline \multicolumn{6}{|l|}{ Crohn's disease } \\
\hline 1 & 44 & 57 & 42 & 32 & 1.9 \\
\hline 2 & 11 & 77 & 45 & 27 & 1.6 \\
\hline 3 & 18 & 69 & 40 & 26 & 1.5 \\
\hline 4 & 25 & 76 & 43 & 29 & 1.48 \\
\hline 5 & 46 & 66 & 57 & 13 & $4 \cdot 3$ \\
\hline 6 & 79 & 74 & 50 & 20 & $2 \cdot 5$ \\
\hline 7 & 37 & 71 & 50 & 17 & $2 \cdot 9$ \\
\hline 8 & 10 & 83 & 42 & 39 & 1.07 \\
\hline 9 & 5 & 68 & 17 & 54 & $0 \cdot 31$ \\
\hline 10 & 33 & 56 & $19 \cdot 2$ & $43 \cdot 5$ & 0.44 \\
\hline
\end{tabular}

${ }^{*}$ :Results expressed as mean $\pm \mathrm{SD}$ 


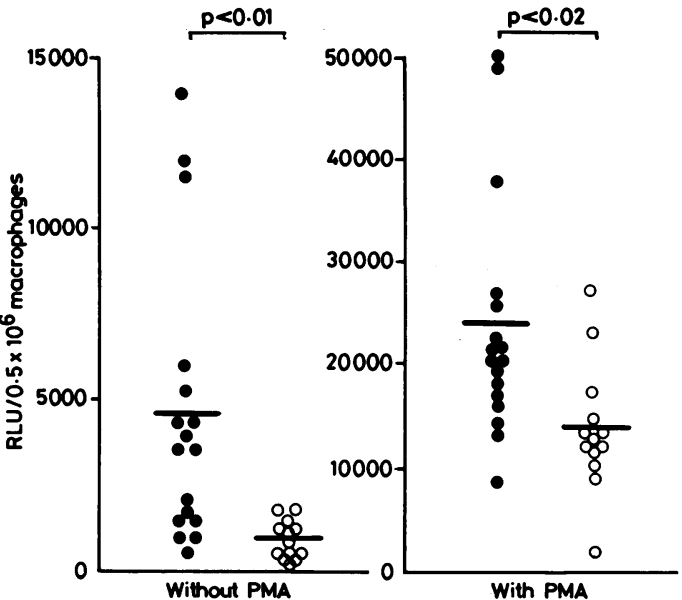

Fig. 2 Spontaneous and phorbolmyristate acetate (PMA) induced superoxide anion production by alveolar macrophages collected by bronchoalveolar lavage $(B A L)$ in 13 controls $(\mathrm{O})$ and 17 Crohn's disease patients $(\mathrm{O})$.

Reduced carbon monoxide diffusing capacity without restrictive ventilatory disorder was found in 10 cases. It was associated with lowered $\mathrm{PaO}_{2}$ in one and with increased residual volume and/or low forced expiratory volume in one second suggesting an obstructive ventilatory disorder in two. If carbon monoxide diffusing capacity is corrected according to blood haemoglobin levels, ${ }^{35}$ however, only three patients with an obstructive or restrictive syndrome have actually a reduced carbon monoxide diffusing capacity. Two patients had normal forced vital capacity and decreased forced expiratory volume in one second and residual volume. Pulmonary function tests were done again six months later in seven patients with initial abnormalities which were found basically unchanged.

\section{$3{ }^{67} \mathrm{Ga}$ SCANNING}

No pulmonary or mediastinal uptake was observed in nine tested patients.

\section{PULMONARY SCANNING}

The percentage of gaseous Xenon remaining in lungs at one minute was identical in Crohn's disease patients and controls: $8 \cdot 3 \pm 8 \cdot 6$ and $4 \cdot 8 \pm 3$ (Fig. 3). Pulmonary perfusion scanning showed a decreased perfusion of higher portion of lung associated with an hyperperfusion of lung bases. This resulted in a significant increase of the distance delta between both centres of gravity of lung perfusion and ventilation: $13 \pm 3 \%$ in Crohn's disease patients versus $8 \cdot 7 \pm 4 \cdot 3$ in controls $(p<0 \cdot 05)$ (Fig. 3$)$.

\section{BLOOD TESTS}

Serum angiotensin converting enzyme levels were significantly lower in patients $(14 \cdot 1 \pm 5 \cdot 1 \mathrm{u} / \mathrm{ml})$ than in controls $(25.2 \pm 4.7 \mathrm{u} / \mathrm{ml})(\mathrm{p}<0.001)$. Serum $\beta 2$ microglobulin levels were significantly higher in patients $(3.4 \pm 1 \cdot 1 \mathrm{mg} / \mathrm{l})$ than in controls $(2 \cdot 1 \pm 0.9$ $\mathrm{mg} / \mathrm{l}),(\mathrm{p}<0.001)$. Circulating immune complexes were present in three of seven patients with lymphocyte alveolitis, and in one patient with normal bronchoalveolar lavage.

6 CORRELATION OF BAL RESULTS WITH CLINICAL PARAMETERS, PULMONARY SCANNING AND FUNCTION TESTS AND BIOLOGICAL DATA (Table 2)

There was no apparent correlation between abnormal bronchoalveolar lavage and systemic disorders, activity of intestinal disease, or drug treatment. Patients with alveolitis have a longer (although not significant) Crohn's disease duration (61 \pm 70 months) than those without $(26 \cdot 8 \pm 25$ months). Alveolar lymphocytosis is more frequent in patients having anal Crohn's disease (six of eight patients) than in those without (six of 14 patients) $(p<0.05)$. There was no correlation between alveolar lymphocytosis and pulmonary function tests

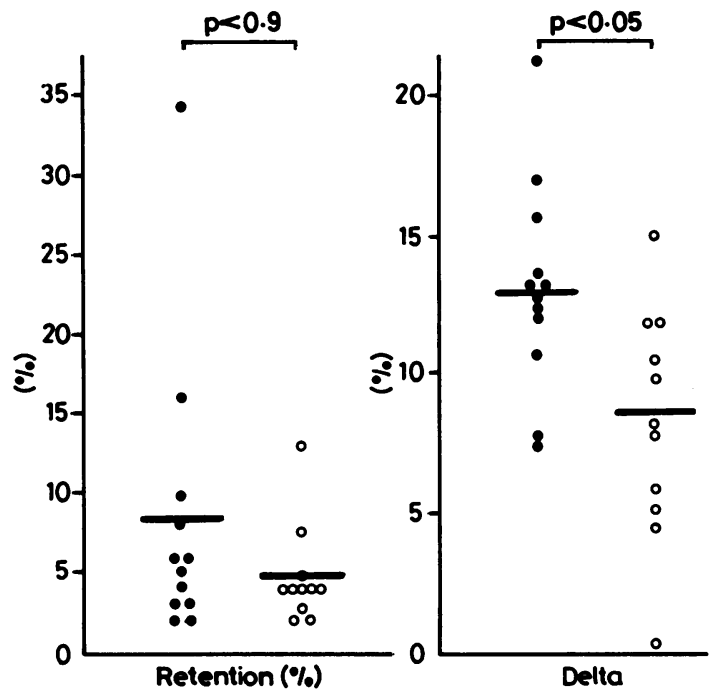

Fig. 3 Pulmonary scintiscanning data in 11 controls $(\mathrm{O})$ and 12 patients with Crohn's disease (O). Pulmonary gas retention was the percentage of gas remaining in the lung one minute after the steady state ventilation was obtained. Pulmonary 'delta' was the distance between both centres of gravity of lung perfusion and ventilation, and was expressed as percentage of the total lung height (see text). 
Table 2 Clinical, biological and pulmonary data in 12 patients with Crohn's disease having BAL lymphocytosis (>18\% alveolar lymphocytes) and 10 patients without BAL lymphocytosis.

\begin{tabular}{lcc}
\hline & $\begin{array}{l}\text { CD with raised lavage } \\
\text { lymphocytes } \\
n=12\end{array}$ & $\begin{array}{l}\text { CD without raised lavage } \\
\text { lymphocytes } \\
n=10\end{array}$ \\
\hline Age (yrs) & $29 \cdot 7 \pm 8 \cdot 1^{*}$ & $26 \cdot 1 \pm 7 \cdot 0 \dagger$ \\
CD duration (months) & $61 \cdot 0 \pm 70^{*}$ & $26 \cdot 8 \pm 25 \dagger$ \\
CDAI & $208 \pm 94^{*}$ & $206 \pm 78 \dagger$ \\
Weight loss (\%) & $13 \cdot 5 \pm 9 \cdot 4^{*}$ & $14 \pm 7 \cdot 6 \dagger$ \\
Orosomucoïd (mg/l) & $1483 \pm 953^{*}$ & $1775 \pm 1048 \dagger$ \\
Blood lymphocyte (ml) & $1424 \pm 787^{*}$ & $1718 \pm 849 \dagger$ \\
Albumin (g/l) & $28 \cdot 7 \pm 3 \cdot 9^{*}$ & $30 \cdot 4 \pm 4 \cdot 4 \dagger$ \\
FVC (\%) & $94 \pm 15^{*}$ & $100 \pm 19 \dagger$ \\
FEV1 (\%) & $97 \pm 24^{*}$ & $104 \pm 27 \dagger$ \\
DLCO (\%) & $75 \pm 3^{*}$ & $69 \pm 20 \dagger$ \\
Basal chemiluminescence of BAL cells (RLU) & $5271 \pm 4542^{*}$ & $2877 \pm 1237 \dagger$ \\
\hline
\end{tabular}

BAL-bronchoalveolar lavage, CD—Crohn's disease, FVC—forced vital capacity, FEV1-forced expiratory volume in 1 second, DLCO—carbon monoxide diffusing capacity, RLU—relative luminescent units.

${ }^{*}$ Results expressed as mean $\pm \mathrm{SD}$.

$\nmid$ No difference versus $C D$ with raised alveolar lymphocytes.

abnormalities, pulmonary scanning results, blood test data, or superoxide anion production by alveolar macrophages. There was a significant correlation between reduced carbon monoxide diffusing capacity and the distance delta between both centre of gravity of lung perfusion and ventilation $(r=0.68$ $\mathrm{p}<0.05)$. Four patients with an obstructive syndrome had a longer Crohn's disease history (66 \pm 18 months) than 15 without ( $30 \pm 8$ months) $(\mathrm{p}<0 \cdot 001)$.

\section{Discussion}

The main finding of our study is a high proportion $(54 \%)$ of increased alveolar lymphocytosis among patients with Crohn's disease, free of clinical pulmonary symptoms and with normal chest roentgenograms. Alveolar lymphocytosis is persistent as it was present at the same level six months later in four tested patients.

The significance of increased percentage of bronchoalveolar lavage lymphocyte in Crohn's disease is not clear. An increased percentage of bronchoalveolar lavage lymphocytes reflects a shift in the relative proportion of alveolar cells which is classically associated with an alveolitis - that is, an accumulation of immune and inflammatory cells within the alveolar structures. ${ }^{36}$ It is well recognised that such alveolar lymphocyte alveolitis, is a characteristic feature of all classic lung granulomatous disorder, such as, sarcoïdosis, hypersensitivity pneumonitis, and berylliosis. These diseases were excluded from our study.
An iatrogenic mechanism could be discussed. Indeed most patients with Crohn's disease are treated with sulphasalazine at some stage of the disease and could develop a latent sensitisation to the drug. Previous studies of pulmonary function in inflammatory bowel disease have shown, however, that variations in lung function, especially reduced carbon monoxide diffusing capacity are not a consequence of drug therapy. ${ }^{22}$ Moreover 18 of our patients had not received sulphasalazine during the three months before the study. Finally sulphasalazine is known as inducing hypersensitivity pneumonitis. This would have resulted in an increased number of eosinophil polymorphonuclear cells in the bronchoalveolar lavage cell count which we did not observe.

Our study shows the capacity of alveolar macrophages from patients with Crohn's disease to produce superoxide anion. The increased production of superoxide anion is likely to be caused by alveolar macrophages as there were neither neutrophils nor eosinophils polymorphonuclear cells in bronchoalveolar lavage specimens from controls or patients, and as lymphocytes do not produce superoxide anion. The release of superoxide anion by macrophages was not associated with increased alveolar lymphocytosis in patients with Crohn's disease in contrast with previous observations in patients with sarcoïdosis. ${ }^{36}$ The production of superoxide anion may reflect a spontaneous activation of alveolar macrophages similar to that of circulating monocytes observed in Crohn's disease. ${ }^{37-39}$ Whether or not release of reactive material by macrophages may play a role in tran- 
sient alteration of pulmonary function or in the occurrence of alveolar lymphocytosis remains to be established.

It is currently accepted that part of the immune system specific to the gastrointestinal tract is common to all mucosal surfaces. ${ }^{40}$ Therefore the association of Crohn's disease and lymphocyte alveolitis and/or superoxide anion production by alveolar macrophages may be the result of an immunological mechanism: the lymphocytes and/or the macrophages sensitised to antigen at one mucosal site could circulate and inhabit the mucosal surfaces of the lung.

Abnormal pulmonary function tests were noted in 15 of 21 patients and were similar to findings previously described in inflammatory bowel disease. ${ }^{22-26}$ Abnormal pulmonary function tests do not seem to be related to alveolar lymphocytosis which is therefore latent (Table 2).

Our patients have an increased physiologic dead space in the upper part of their lung related to any hypoperfusion of this lung portion. This may explain in part reduced carbon monoxide diffusing capacity in several Crohn's disease patients. Different perfusion rates in lung upper and lower part in patients with Crohn's disease is unexplained. Release of vasoactive substances inducing vasodilation in pulmonary circulation may be one hypothesis. Alveolar distension resulting in an increase of alveolar pressure is another hypothesis suggested by the existence of an obstructive ventilatory disorder in some patients. Crohn's disease related distensibility abnormalities of pulmonary vessels in lung bases under hydrostatic pressure could be another explanation. 4142

Pulmonary abnormalities in Crohn's disease are identical to some reported in pulmonary sarcoïdosis: alveolar lymphocytosis and activation of alveolar macrophage. Some differences exist between Crohn's disease and sarcoïdosis, however: (a) Crohn's disease patients had dramatically low serum angiotensin converting enzyme; (b) no mediastino pulmonary ${ }^{67} \mathrm{Ga}$ uptake was observed in Crohn's disease patients; (c) $\mathrm{OKT}_{4}{ }^{+}$lymphocytes are not always raised in Crohn's disease patients. ${ }^{36}$ Whatever the significance of our data, persistent abnormalities of bronchoalveolar lavage and pulmonary function tests suggest a latent involvement of the lung in Crohn's disease which merits further investigation.

\section{References}

1 Rankin GB, Watts D, Melnyk CS, Kelley ML. National cooperative Crohn's disease study: extraintestinal manifestations and perianal complications. Gastroenterology 1979; 77: 914-20.
2 Rodgers BHG, Clark LM, Kirsner JB. The epidemiologic and demographic characteristics of inflammatory bowel disease: an analysis of a computerized file of 1400 patients. J Chron Dis 1971; 24: 743-73.

3 Butland RJA, Cole P, Citron KM, Turner-Warwick M. Chronic bronchial suppuration and inflammatory bowel disease. $Q J$ Med 1981; 197: 63-75.

4 Higenbotam T, Cochrane GM, Clark TJM, Turner D, Millis R, Seymour W. Bronchial disease in ulcerative colitis. Thorax 1980; 35: 581-5.

5 Kraft SC, Earle RH, Roesler M, Esterly JR. Unexplained broncho-pulmonary disease with inflammatory bowel disease. Arch Intern Med 1976; 136: 454-59.

6 Shah SM, Texter EC, White MJ. Inflammatory bowel disease associated with granulomatous lung disease. Report of a case with endoscopic findings. Gastrointest Endosc 1976; 23: 98-9.

7 Collins WJ, Bending DW, Taylor WF. Pulmonary vasculitis complicating childhood ulcerative colitis. Gastroenterology 1979; 77: 1051-3.

8 Forrest JAM, Schearman DJC. Pulmonary vasculitis in ulcerative colitis. Am J Dig Dis 1975; 20: 482-6.

9 Isenberg JI, Goldstein H, Korn AR, Ozeran RS, Rosen V. Pulmonary vasculitis: an uncommon complication of ulcerative colitis. $N$ Engl J Med 1968; 279: 1376-7.

10 McKee AL, Rajapaksa A, Kalish PE, Pitchumoni AS. Severe interstitial pulmonary fibrosis in a patient with chronic ulcerative colitis. Am J Gastroenterol 1983; 78: 86-9.

11 Henrion F, Bretagne MC, Neimann L, Flechon PE, Canton P, Hoeffel JC. Association exceptionnelle de lésions pulmonaires, cutanées et d'une iléite terminale chez un enfant de 11 ans. J Radiol 1982; 63: 123-6.

12 Meadway J. Ulcerative colitis, colitic spondylitis and associated apical pulmonary fibrosis. Proc R Soc Med 1974; 67: 324-5.

13 Anonymous. Sulfasalazine induced lung disease. Lancet 1974; 2: 504-5.

14 Berliner S, Neeman A, Schoenfeld Y et al. Salazopyrin induced oesinophilic pneumonia. Respiration 1980; 39: 119-20.

15 Constantinidis K. Eosinophilic pneumonia: an unusual side effect of therapy with salicylazosulfapyridine. Chest 1976; 70: 315-6.

16 Davies D, MacFarlane A. Fibrosis alveolitis and treatment with sulphasalazine. Gut 1974; 15: 185-8.

17 Jones ER, Malone DNS. Sulfasalazine induced lung disease. Thorax 1972; 27: 713-7.

18 Thomas P, Seaton A, Edwards J. Respiratory disease due to sulfasalazine. Clin Allergy 1974; 4: 41-7.

19 Tydd TF, Dyer NH. Sulfasalazine lung. Med J Aust 1976; 1: $570-3$

20 Williams T, Eidus L, Thomas P. Fibrosing alveolitis bronchiolitis obliterans and sulfasalazine therapy. Chest 1982; 81: 766-8.

21 Yaffe BH, Korelitz BI. Sulfasalazine pneumonitis. Am J Gastroenterol 1983; 78: 493-4.

22 Eade OE, Smith CL, Alexander JR. Pulmonary function in patients with inflammatory bowel disease. $A m J$ Gastroenterol 1980; 73: 154-6.

23 Heatley RV, Thomas P, Prokipchuk EJ, Gauldie J, 
Sieniewicz DJ, Bienenstock J. Pulmonary function abnormalities in patients with inflammatory bowel disease. $Q J$ Med 1982; 203: 241-50.

24 Johnson N, Mee AS, Jewell DP, Clarke SW. Pulmonary function in inflammatory bowel disease. Digestion 1978; 18: 416-8.

25 Pasquis P, Baptiste P, Denis P, Colin R, Lefrancois R. Fonction respiratoire au cours de la maladie de Crohn. Rev Fr Mal Resp 1980; 8: 49-50.

26 Pasquis P, Colin R, Denis P, Baptiste P, Galmiche JP, Hecketsweiler P. Transient pulmonary impairment during attacks of Crohn's Disease. Respiration 1981; 41: 56-9.

27 Wallaert B, Colombel JF, Tonnel AB, et al. Evidence of lymphocyte alveolitis in Crohn's disease. Chest 1985; 87: $363-7$.

28 Wallaert B, Aerts C, Bonniere P, et al. Superoxide anion generation by alveolar macrophages in Crohn's disease. $N$ Engl J Med 1985; 312: 444-5.

29 Best WR, Becktel JM, Singleton JW. Redezived values of the eight coefficients of the Crohn's Disease Activity Index (CDAI). Gastroenterology 1979; 77: 843-7.

30 Voisin C, Gosselin B, Tonnel AB, et al. Valeur et limites actuelles de l'étude des populations cellulaires recueillies par lavage bronchoalvéolaire. Acta Endoscopica 1982; 12: 381-90.

31 Aerts C, Wallaert B, Grosbois JM, Voisin C. Release of superoxide anion by alveolar macrophages in pulmonary sarcoïdosis. Ann NY Acad Sci 1986; 465: 193-200.

32 Quanjer PH. Standardized lung function testing report working party "Standardization of lung function tests". Luxembourg: European Community for Coal and Steel, 1981.

33 Lieberman J. Elevation of serum angiotensin-convert- ing enzyme level in sarcoïdosis. Am J Med 1975; 59: 365-72.

34 Krc I, Fische-Rova E, Kojecky Z, Benysek L, Matouskova I. Increased serum $\beta 2$-microglobulin level in patients with inflammatory bowel disease. Boll ist Sieroter Milan 1982; 61: 230-4.

35 Dinakara P, Blumenthal WS, Johnson RF, Kauffman IA, Solnick PB. The effect of anaemia on pulmonary diffusing capacity with dezivation of a correction equation. Am Rev Resp Dis 1970; 102: 965-9.

36 Crystal RG, Bitterman PB, Rennard SI, Hance AJ, Keogh BA. Interstitial lung disease of unknown cause. $N$ Engl J Med 1984; 310: 154-66.

37 Bloomfield RS, Maxwell WJ, Walsh JP, et al. Essential fatty acid composition and prostaglandin $\mathrm{E}$ production by peripheral blood cells from patients with Crohn's disease. [Abstract]. Gut 1984; A: 1157.

38 Ganguly NK, Lloyd B, Price CP et al. Acid hydrolases in monocytes from patients with inflammatory bowel disease, chronic liver disease, rheumatoid arthritis. Lancet 1978; 20: 1073-5.

39 Mee AS, Jewell DP. Monocytes in inflammatory bowel disease: monocyte and serum lysosomal enzyme activity. Clin Sci 1980; 58: 295-300.

40 Bienenstock $\mathrm{J}$. The physiology of the local immune response and the gastrointestinal tract. Progr Immunol 1974; 4: 197-207.

41 Bryan AC, Bentivoglio LG, Beerel F, Mac Leish H, Zidulka A, Bates DV. Factors affecting regional distribution of ventilation and perfusion in the lung. $J$ Appl Physiol 1964; 19: 395-402.

42 West JB. Regional difference in the lung. In: West JB ed. Blood flow. New York: Academic Press, 1977: 85-165. 